\title{
Exploration on the Professional Development Path of Teachers Based on Students' key Competences
}

Qian Zheng: School of Mathematical Sciences, University of Jinan, Jinan, Shandong 250022, P R China.

-Zhenlai Han: School of Mathematical Sciences, University of Jinan, Jinan, Shandong 250022, P R China.

Shurong Sun: School of Mathematical Sciences, University of Jinan, Jinan, Shandong 250022, P R China.

ABSTRACT: The cultivation of students' core literacy is a hot topic in the education sector at this stage. Teachers play an important role in the formation of students' core literacy. Under the core literacy concept, the society puts higher demands on teachers. Teachers also need to face the transformation of the knowledge base to the competency standard, the transition from "teacher center" to "student center", "de-situation teaching" to "situation teaching". A series of challenges. In order to truly develop the core literacy of students, it is necessary to establish a national core literacy standard for teachers, increase teacher training based on core literacy, and continuously learn and develop the teachers themselves to lead the professional development of teachers and develop core literacy for students. The relevant content is integrated into it.

Keywords: Core literacy, Teacher professional development, Teachers, Student development.

\section{Introduction}

At present, key competences has become a hot topic of discussion in the basic education community. It provides new directions and possibilities for the reform of basic education curriculum and the integration of teaching objectives. In March 2014, China stated for the first time the connotation of "key competences" in the "Opinions on Comprehensively Deepening the Curriculum Reform and Implementing the Fundamental Tasks of taking high moral values establishment and people cultivation ". In 2016, the Chinese Ministry of Education officially promulgated the overall framework for the development of students' key competences and clearly pointed out the direction of talent training. So how to put the overall framework of developing students' key competences into practical education and teaching activities has become the focus and difficulty of education at this stage. It is undeniable that teachers dominate the transformation. Therefore, in order to better integrate key competences into the actual education and teaching process, it is also essential to lead the professional development of teachers.

\section{The Content of Students' Key Competences}

Internationally, in response to the challenges of the 21 st century knowledge economy. The Organization for Economic Co-operation and Development (OECD) launched the key competences framework project in 1997 under the leadership of the Swiss Federal Statistical. And in the final report of 2003, "The key competences for a successful life and a sound society" (Rychen and Salganik 2003) pointed out that key 


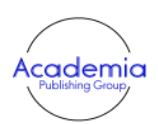

Research in Social Sciences

Vol. 1, No. 1, pp. 27-31

2018

DOI: 10.53935/2641-5305.v1i1.4

${ }^{2}$ Corresponding Author: Zhenlai Han

Email: hanhenlai@163.com

Funding: This study received no specific

financial support.

Acknowledgment: This paper is the stage

achievement of Jinan University Graduate

achievement of Jinan University Graduate

Education Innovation Project "Research on

Evaluation Criteria and System of Graduate

Education Quality for Professional Degrees in
Shandong Province under the Background of

Shandong Province under the Background of
"Double-first-class"Construction" (No. JDY1601)

"Double-first-class"Construction" (No. JDY1601)
and "Research on Construction and

and "Research on Construction and

Graduate Education of Master of Education"

(No. JDY1707).

Article History:

Received: 10 August 2018

Revised: 17 September 2018

Accepted: 19 October 2018

Published: 21 November 2018

C) 2018 by the authors; licensee Academic

Publishing Group

128 competences is not only for dealing with society, but also an important factor for individual transformation of society. Therefore, the determination of key competences is not only based on the needs of individuals and society, but also on the target nature of individuals and society, focusing on innovation, autonomy and selfmotivation (OECD, 2005). The OECD's presentation of key competences represents the highest level of international core literacy research. In 2006, the EU redefined key competences from the three dimensions of knowledge, skills and attitudes. They believe that key competences is a set of knowledge, skills and attitudes that everyone needs to develop, integrate and be competent in the knowledge society collection (The European Parliament and the Council of the European Union, 2009). After that, all countries in the world have actively proposed a key competences framework to adapt to their own development. However, there is a common place in these key competences frameworks. In the information age, the common pursuit of human development goals in the world reflects the development trend of world education. Therefore, in order to continue to lead in the international arena, China needs to construct a key competences system that is in line with China's national conditions and student development.

In the context of internationalization, we will actively study the research on key competences in other countries and combine the characteristics of China's educational development. In March 2014, the Ministry of Education stated for the first time in the "Opinions on Comprehensively Deepening the Reform of Curriculum Implementation and Implementing the Fundamental Tasks of taking high moral values establishment and people cultivation " that "key competences" is a must-have character and key for students to adapt to future social development and personal development. Ability, and after two years, the core framework of key competences and the core literacy concept of the core are given from the three dimensions of cultural foundation, independent development and social participation. It is proposed that the comprehensive performance of key competences of Chinese students is humanistic, scientific, learning, and healthy. Six literacy of life, responsibility, practice and innovation (Chai and Liu 2016). It highlights the important position of key competences in China's education.

For the students who are currently educated, the key competences is not only relying on the innate ability, but on the basis of genetics, it gradually forms and develops in the process of students' growth and development. The process of maturity and progress of students is impossible to complete in a short period of time, but gradually and continuously for a lifetime in different stages of development. Therefore, the key competences of students in the basic education stage is constantly formed in the daily learning and life process, and under the guidance of teachers, it is obtained through active education and participation in practical activities in the direction that meets the needs of social development. Therefore, under the background of key competences, teachers' own quality, educational philosophy and professional development direction are crucial. How to improve the ability of teachers, let teachers keep up with the trend of the times, and build a specific professional development path has become a key issue for teachers today. The following will specifically explore the problems faced by teachers in the key competences perspective and the path of professional development.

\section{Problems Faced by Teachers in the Perspective of Key Competences}

Under the key competences, the "people-oriented" education concept is put forward, and the foothold of school education has returned to "people". Therefore, teachers should take students as the main body, base on the foundation of the future society, and train students to adapt to lifelong development and social development. A must-have character and key competencies to achieve the ultimate meaning of education. The emergence of these changes has placed higher demands on teachers and teachers are facing greater challenges.

\subsection{The Shift from the Knowledge Base to the Competency Standard}

In order to make up for the shortcomings of the double-base teaching, in 2001 the Ministry of Education put forward the "three-dimensional goal" education concept in the "Basic Education Curriculum Reform Outline (Trial)", which promoted the reform of education and teaching to a certain extent. However, various problems of different sizes still appear in the classroom teaching. Compared with the double-base teaching, the three-dimensional goal has not been changed in essence, and still only pays attention to the results that the basic knowledge should achieve, which limits the diversity and flexibility of the classroom form. Moreover, when teachers design three-dimensional goals, due to the pressure of entering a higher school and the limitations of the current evaluation model of education and teaching, most teachers are trapped in the 


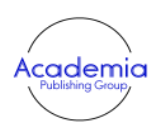

Research in Social Sciences

Vol. 1, No. 1, pp. 27-31

2018

DOI: 10.53935/2641-5305.v1i1.4

Corresponding Author: Zhenlai Han

Email: hanhenlai@163.com

Funding: This study received no specific

financial support.

Acknowledgment: This paper is the stage
achievement of Jinan University Graduate

achievement of Jinan University Graduate

Education Innovation Project "Research on

Evaluation Criteria and System of Graduate

Education Quality for Professional Degrees in

Shandong Province under the Background of

"Double-first-class"Construction" (No. JDY1601)

and "Research on Construction and
Implementation of Quality Guarantee System for

Graduate Education of Master of Education"

(No. JDY1707).

Article History:

Received: 10 August 2018

Revised: 17 September 2018

Accepted: 19 October 2018

Published: 21 November 2018

C) 2018 by the authors; licensee Academic

Publishing Group

| 29 quagmire of knowledge. Still based on the teaching of knowledge points, knowledge is absolute and sacred, the system of disciplines becomes fragmented, can not reflect the rigor of subject logic, and can not reflect the correlation between knowledge. Knowledge-based education has become the focus of school education at this stage, and the cultivation of abilities and literacy has been marginalized and weakened. In turn, teachers and students are trapped in a complex subject knowledge system, students eventually become test machines without temperature, and the knowledge learning hidden behind the results and the test is the focus of classroom teaching. The school education and teaching classroom has become a high-score, low-energy, lack of literate "talent" training ground. What is more remarkable is that while the personality and creativity are stifled, the young mind is deeply stinged and even penetrated.

The key competences of each discipline points to the "people-oriented" education concept, guiding the school education to construct a multi-disciplinary evaluation model of education and teaching, so that the majority of teachers and students can escape from the sea of questions, and improve their ability and accomplishment while learning knowledge. Cultivate the talents needed for social development. In the process of students' growth, the study of knowledge has laid a solid foundation for their development, and the education and teaching activities of the school cannot leave the transmission of knowledge. However, the school's education and teaching activities are not only the transfer of knowledge, the overall development of students is not simply dependent on the mastery of knowledge, classroom teaching ultimately points to the overall development of students. Therefore, through classroom teaching, teachers should guide students through the teaching process and practice to experience and understand the deep meaning of knowledge learning, and establish a disciplinary system with individuality. And let students connect knowledge with real life, enhance students' practical application ability, establish a correct outlook on life, values, and enhance their key competences. This is not only the responsibility of the current stage of education, but also the responsibility of the times that teachers must bear, and the declaration of warfare from the key competences to the knowledge base.

\subsection{The Transition from "Teacher Center" To "Student Center"}

For the status of teachers and students in education and teaching activities, there has been a debate between "teacher-centered theory" and "student center theory" since ancient times. As a representative of the "traditional education school", Herbart believes that educational activities should be centered on teachers and centered on books. The growth of students depends on the leadership and authority of teachers (Shen, 2018). However, under the influence of the current arduous task of teaching and the single evaluation mode, many teaching classes at this stage are still based on "full house irrigation". From the beginning to the end, only teachers instruct students to inculcate knowledge and stereotype training, ignoring teachers and students. The interaction between the students can only be accepted as a container.

The key competences proposal clearly answers the question of "what kind of person should be cultivated in education?" All the educators have always faced different characteristics, so the current stage of education should change the concept, focus on the fresh student groups and individuals, and carry out education and teaching activities around the students, always remembering Student-centered. Therefore, how to truly implement the student center in the school education and teaching activities has become a problem that every teacher must ponder.

The mathematics classroom has changed from the "teacher-centered" model to the "student-centered" model. The most fundamental change is to allow students to effectively integrate into the classroom and participate in the process of knowledge exploration. Through practical problems or small stories, teachers can guide students to use their knowledge to think and solve problems autonomously, fully stimulate students' enthusiasm for learning, deepen their understanding and understanding of learning content, and make the classroom full of vitality and passion. At the same time, in the process of inquiry, the transformation of students' thinking has been realized, and their ability and quality have been improved.

\subsection{The Transition from "Scenario Teaching" To "Situation Teaching"}

From the perspective of knowledge generation, the most basic and effective way for students to understand and apply knowledge is to feel and think in the real situation, and to consolidate in the process of knowledge application. However, at the current stage of school teaching, the school as an independent individual, largely out of the real social life, resulting in the teaching classroom is also far from life, leading to 
the emergence of the "go to the scene" teaching mode. Therefore, teachers should carefully design the teaching before the class, create appropriate teaching situations, combine abstract knowledge with fresh scenes, and provide students with the opportunity to use the theoretical knowledge to solve practical problems.

Standing on the height of cultivating students' core literacy, teachers should gradually realize the transition from "de-situation teaching" to "situational teaching", correctly grasp the effective relationship between teaching content and actual social life, according to the existing knowledge structure of students and Emotional experience, creating rich learning situations and inquiry activities, fully stimulating students' enthusiasm for learning, improving students' abilities and self-cultivation, and realizing the development of students in the primary education stage.

\section{Teacher Professional Development Path Based On Students' Key Competences}

Classroom teaching is a bilateral interactive activity consisting of the teaching of teachers and the learning of students. There is no doubt that teachers play a guiding role in the classroom teaching process. The key competences of students is gradually formed and developed in daily learning and life, so teachers are one of the important factors affecting the development of students' key competences. Therefore, countries and international organizations around the world attach great importance to the professional development of teachers based on key competences, and achieve the goal by enacting a series of standards for teachers' key competences and establishing a teacher training system (Lin, 2016). In China, in order to better implement and cultivate the key competences of students, it is necessary to improve the professional quality of teachers, lead the professional development of teachers, and integrate the relevant content of the development of students' key competences.

\subsection{Develop A Unified Teacher Key Competences Standard}

In the process of developing students' key competences, the guiding role of teachers cannot be ignored. The level of teacher guidance depends on the professionalism of the teacher. The emergence of key competences puts higher demands on teachers' professional literacy. How to adapt to the requirements of the development of the times and meet the needs of students' growth has become an inescapable problem in the professional development of teachers at this stage. Based on the requirements and comprehensive performance of students' key competences, the corresponding key competences standards of teachers are developed to point the direction for the professional development of teachers. Promoting the development of teachers' professionalism while promoting the development of teachers' key competences has become a common practice for countries and international organizations to promote key competences. Therefore, China should also develop a unified key competences standard for teachers, and introduce specific frameworks and contents for teacher professional development to enhance the quality and professionalism of teachers in China.

\subsection{Increase Teacher Training Based On Key Competences}

Through contact with primary and secondary school teachers, it can be found that most front-line teachers do not know what is key competences and what is the key competences of the discipline. The current teacher's concern is still the student's achievement. The teaching goal follows the three-dimensional teaching goal. When participating in the key competences-related lectures, it is also full of complaints. It is considered that the new educational concept is not relevant to the actual teaching. It is purely a fallacy. Your own precious time. The attitude of the teacher determines the direction and extent of the student's development. Only when the teacher realizes the importance of developing the key competences of the students, and the key competences from the bottom of the heart, the key competences can be implemented and better developed in the actual teaching. Therefore, it is necessary to increase teacher training based on key competences, let teachers understand the background of key competences, clarify the essence of key competences, and realize that key competences is the ultimate goal of education. At the same time, strengthen the interpretation of the key competences and curriculum standards of the disciplines, further deepen the teachers' understanding of the key competences of the disciplines, and give play to the guiding role of the key competences of the disciplines in the curriculum teaching. 


\subsection{Self-Learning and Development of Teachers}

Whether it is the development of a unified teacher key competences standard or the addition of key competences-based teacher training, these are external factors and forces that promote the professional development of teachers. External factors can only work if they are based on internal factors. Teachers only actively pursue independent professional development and transcendence, constantly learning new knowledge and theory, and improving personal accomplishment are the fundamentals for teachers to implement key competences in teaching. As the existence of life, man's nature and value lies in transcendence, and realizes the ideal pursuit in transcendence. As a living individual, the teacher also realizes the development of self in continuous learning and transcendence. As a new educational concept, key competences puts forward higher requirements for the development of students. On the other hand, it poses greater challenges to teachers' educational concepts, teaching organization, teaching methods, education and teaching innovation. Only the teachers themselves actively learn and reflect, realize the importance of their own responsibilities and key competences in education and teaching, and actively change and construct, in order to achieve a gorgeous turn in the key competences-based education reform, truly in teaching Pay attention to student development and cultivate students' key competences."

\section{Conclusion}

It is of great significance to promote the professional development of teachers on the basis of cultivating students' key competences. It is to improve the quality of the Chinese teachers at the present stage, implement the development of students' key competences, and provide more high-quality talents for social development.

Teacher professional development as a way for teachers to surpass themselves is worthy of the attention of every teacher. Thus teachers and students work together to achieve a win-win situation.

\section{References}

Rychen, D.\& Salganik, L.(eds.). (2003). key competencess for a Successful Life and Well-Functioning Society. Hogrefe \& Huber, Gottingen.

OECD. (2005). The Definition and Selection of Key Competencies: Executive Summary [EB/OL]. Available from: http://www.oecd.org/pisa/35070367.pdf. [Accessed 2005-05-27].

The European Parliament and the Council of the European Union, (2009). Recommendation of the European Parliament and of the Council of 18 December 2006 on key competences for Lifelong Learning. Official Journal of the European Union, (8).

Chai Wei, \& Liu Bozhi. (2016). Six literacy establishes the benchmark of student growth. China Education News, 20169-14 (1).

Shen Pingxia. (2018). Exploration of the Professional Development Path of Teachers Based on Students' key competences. Education Guide, 8: 63-67.

Lin Chongde. (2016). Research on the Key Competences of Student Development in the 21st Century. Educational Science Forum, 20: 24.

Research in Social Sciences

Vol. 1, No. 1, pp. 27-31

2018

DOI: 10.53935/2641-5305.v1i1.4

Corresponding Author: Zhenlai Han

Email: hanhenlai@163.com

unding: This study received no specific

financial support.

Acknowledgment: This paper is the stage

achievement of Jinan University Graduate

Education Innovation Project "Research on

Evaluation Criteria and System of Graduate

Shandong Province "Double first-class"Constrich" (No. JDYI60i) "Dnd "Reseclass "Construction" (No. JDYI601) "Dimplementeach on Construction and Graduention of Quality Guarantee System for Graduate Education of Master of Education No. JDYI707).

Received: 10 August 2018

Revised: 17 September 2018

Accepted: 19 October 2018

Published: 21 November 2018

(2) 2018 by the authors; licensee Academic

Publishing Group

| 31 